УДК 34.01

DOI https:/ / doi.org/10.32837/yuv.v0i1.1619

\author{
О. Донченко, \\ кандидат юридичних наук, \\ асистент кафедри людських прав \\ Чернівецького національного університету імені Юрія Федьковича \\ О. Бунчук, \\ кандидат юридичних наук, доцент, \\ доцент кафедри людських прав \\ Чернівецького національного університету імені Юрія Федьковича
}

\title{
КУЛЬТУРА ПРАВ ЛЮДИНИ: \\ МІЖНАРОДНО-ПРАВОВІ СТАНДАРТИ Й НАЦІОНАЛЬНИЙ ДОСВІД
}

\begin{abstract}
Сучасний стан культури прав людини у світовому співтоваристві характеризується неоднозначністю й суперечливістю. 3 одного боку, права людини майже одностайно визнаються цінністю загальнолюдської культури. Існує розгалужена система міжнародних стандартів та інституцій щодо іх регламентації й захисту. 3 іншого боку, повага до прав людини, їх дотримання, гарантування нівелюються та знецінюються в умовах сучасних міжнародних збройних конфліктів, катастроф техногенного характеру, зменшення матеріальних і природних ресурсів тощо.

В Україні рівень культури прав людини як окремих індивідів, так і суспільства загалом не $є$ високим. Це зумовлено й історичним минулим (адже українському суспільству не притаманний індивідуалізм, у контексті якого формувалися уявлення про права людини на Заході), і реаліями сьогодення. Збройний конфлікт на сході України, окупація Автономної Республіки Крим є серйозними викликами правам людини, фактично спростуванням поваги до людського життя й людської гідності. У такій ситуації важливо, щоби громадяни, представники державних структур та організацій громадянського суспільства мали знання у сфері прав людини й практичні навички щодо їх реалізації та захисту.
\end{abstract}

Проблематика культури прав людини досліджується в працях багатьох вітчизняних і зарубіжних учених, зокрема Л.Ш. Белла, Р. Голдстоуна, Н.А. Горбової, С.П. Добрянського, А. Мixp, О.С. Мордовця, Є.M. Павленко, П.М. Рабіновича, Дж. Садізоди, Ф. Франціоні й інших. Проте сьогодні деякі аспекти культури прав людини, які мають методологічне і практичне значення, потребують подальшого теоретичного облрунтування.

Метою статті є дослідження міжнародно-правових стандартів і національного досвіду формування культури прав людини у сфері освітнього та науково-дослідного напрямів.

Міжнародне співробітництво в умовах сьогодення $€$ вагомим чинником формування культури прав людини як в Україні, так і в більшості країн світу. Найбільше значення при цьому відіграє виконання зобов'язань, що випливають 3 універсальних і регіональних міжнародних нормативно-правових актів, які спрямовані на освіту й виховання в галузі прав людини.

Зауважимо, що культуру прав людини ми розглядаємо як складник правової культури, визначаємо як систему поглядів, емоцій і почуттів, ціннісних орієнтацій і знань, заснованих на визнанні й повазі прав людини, а також практичних навичок і вмінь 
щодо їх реалізації та захисту. Аналогічний підхід до елементів культури прав людини міститься у вітчизняній юридичній науці [1, с. 17].

Діяльність значної кількості міжнародних i регіональних організацій включає комплекс заходів з інформування громадськості про права людини. На особливу увагу при цьому заслуговує ООН з питань освіти, науки і культури (ЮНЕСКО), яка багаторазово закликала держави об'єднувати спільні зусилля щодо освіти Й виховання в галузі прав людини, поширювати тексти базових міжнародних документів з прав людини, особливо серед молоді. Зокрема, Генеральною конференцією ЮНЕСКО ще 19 листопада 1974 p. прийнята Рекомендація про виховання в дусі міжнародного взаєморозуміння, співробітництва й миру та виховання в дусі поваги прав людини й основних свобод [9].

Наступним кроком просвітницької діяльності ЮНЕСКО стало прийняття в 1995 р. таких найважливіших документів, як Декларація й Комплексні рамки дій з виховання в дусі миру, прав людини і демократіі, у яких ішлося про те, що освіта повинна спрямовуватися на розвиток знань, цінностей, поглядів і навичок, які сприятимуть повазі прав людини й активній прихильності захисту таких прав, побудові культури миру й демократії. Ці тези підтверджено також у п. 4.1 ст. 4 Декларації принципів толерантності, де зазначається, що «виховання в дусі толерантності починається 3 навчання людей того, у чому полягають їхні загальні права й свободи, щоб забезпечити здійснення цих прав і зміцнити прагнення до захисту прав інших» [3].

Заслуговує на увагу й документ Складові частини загальної стратегіі ЮНЕСКО з прав людини, який прийнятий Виконавчою радою ЮНЕСКО 20 вересня 2002 р. Найважливішими стратегічними цілями при цьому ЮНЕСКО відзначає підтримку включення прав людини до національних систем освіти, уважаючи, що «перед іï держа- вами-членами постає завдання переорієнтації політики в галузі освіти на національному рівні (включаючи національне законодавство) для забезпечення того, щоб іï зміст включав такі цінності, як права людини, мир, демократична участь, толерантність, відмова від насильства й міжкультурне розуміння та щоб відповідні освітні процеси були сумісні 3 вихованням у дусі таких цінностей» (п. 32) [11].

Зауважимо, що це лише деякі міжнародні документи з освіти в галузі прав людини, які сьогодні прийняті в рамках ООН. Також варто відзначити положення Віденської декларації й Програми дій, які схвалені Всесвітньою конференцією з прав людини в 1993 р., Всесвітнього плану дій у галузі навчання прав людини й демократії, затвердженого Міжнародним конгресом 3 навчання прав людини й демократії в Монреалі, Декларації й Програми дій в галузі культури миру, прийнятих 53-ю сесією Генеральної Асамблеї ООН 13 вересня 1999 р., тощо.

Зростання уваги до освіти в галузі прав людини у світі ознаменувалося затвердженням 23 грудня 1994 p. Генеральною Асамблеєю ООН Плану дій на Десятиліття 3 освіти в галузі прав людини Організації Об'єднаних Націй на 1995-2004 роки. Відповідно до Плану, освіта в галузі прав людини визначалася як зусилля 3 навчання, поширення та інформування, які прикладають для створення загальної культури прав людини шляхом прищеплювання знань і навичок, формування позицій, що спрямовані на зміцнення поваги до прав людини й основних свобод; усебічний розвиток людської особистості й почуття людської гідності; сприяння взаєморозумінню, терпимості, гендерній рівності, толерантним відносинам між націями, народами, усунення національної ворожнечі; забезпечення для всіх людей можливості ефективно брати участь у житті вільного суспільства та сприяння заходам $\mathrm{OOH}$, спрямованим на підтримку миру [6].

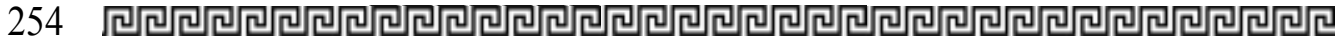


Отже, ООН закликала держави, міждержавні організаціі, владні органи й професійні об’єднання, освітні заклади, усі організації громадянського суспільства до сумісних дій і спільних зусиль для розповсюдження загальної культури прав людини за допомогою інформації, освітніх програм, організації навчальних курсів. За словами першої жінки-президента Ірландії (19901997 роки) і колишнього Верховного комісара ООН з прав людини (19972002 роки) Мері Робінсон: «Десятиліття з освіти в галузі прав людини, оголошене ООН, дає нам загальні рамки, у яких ми зможемо разом працювати для розвитку загальної культури прав людини... Десятиліття з освіти в галузі прав людини - наш загальний проект, й успіх його цілком залежить від внеску кожного в цю загальну всесвітню справу» $[10$, с. 10].

Важливою віхою світового розвитку системи освіти в галузі прав людини стала Всесвітня програма освіти в галузі прав людини, яку затверджено 10 грудня 2004 р. Генеральною Асамблеєю ООН. У подальшому 14 липня 2005 р. Резолюцією 59/113В Генеральна Асамблея ООН схвалила відповідні Плани дій цієї програми й передбачила їх поетапну реалізацію: перший етап - 2005-2009 роки, другий етап - 2010-2014 роки, третій етап 2015-2019 роки.

На наш погляд, досить вдало підходи до освіти в галузі прав людини систематизовано в Посібнику з освіти в галузі прав людини за участі молоді КОМПАС. Це видання вперше опубліковане у 2002 р. за підтримки Ради Європи й у подальшому стало доступним більше ніж 30 мовами. Так, наприклад, у КОМПАСІ зазначено, що Всесвітня програма $\mathrm{OOH}$ освіти в галузі прав людини визначає освіту в галузі прав людини як «освіту, навчання та інформацію, які спрямовані на формування загальної культури прав людини» [5]. Також у посібнику наведено текст Хартії Ради Європи «Освіта для демократичного громадянства та освіта 3 прав людини» (2010р.), відповідно до якої освіта в галузі прав людини визначається як «освіта, навчання, підвищення рівня обізнаності, інформація, методи та вправи, метою яких $€$ шляхом надання учням знань, навичок і розуміння й розвитку їх ставлення та поведінки, розширення можливостей учнів зробити свій внесок у створення й захист загальної культури прав людини в суспільстві задля сприяння й захисту прав та основних свобод людини» [5].

У відповідному розділі КОМПАСА «На шляху до культури прав людини» підкреслюються, що культура прав людини, окрім знань, повинна обов'язково включати повагу до прав людини, адже без поваги завжди будуть мати місце порушення. Водночас пропонується широке розуміння культури прав людини, за відповідного рівня якої люди «володіють знаннями про права людини та поважання їх і про основні свободи; мають почуття власної самоповаги і поваги до інших людей, цінують гідність людини; демонструють ставлення та поведінку поваги до прав інших осіб; практикують справжню гендерну рівність в усіх сферах; виявляють повагу, розуміння і визнання культурного різноманіття, особливо щодо різних національних, етнічних, релігійних, мовних та інших меншин та громад...» [5].

Зрозуміло, що вказані складники культури прав людини в різних суспільствах будуть залежати від соціальних, економічних, історичних і політичних традицій і реалій. Але не викликає сумнівів, що у світовому співтоваристві повинні існувати різні підходи до освіти в галузі прав людини. Саме існування різних поглядів на кращий або найбільш вдалий напрям формування культури прав людини і є показником толерантності, поваги до національної самобутності й культурної різноманітності. Окремі індивіди, національності й народності перебувають на різних етапах розвитку, мають свої невирішені проблеми. Культура прав людини повинна 
грунтуватися на визнанні й повазі відповідних відмінностей.

У 2006 р. в рамках ООН створено новий орган - Рада ООН із прав людини, 3 чим пов'язаний стрімкий розвиток нормативної бази в галузі прав людини. Рада ООН із прав людини в межах своєї компетенції сприяла розробленню Декларації ООН щодо освіти й навчання в галузі прав людини. Генеральна Асамблея ООН ухвалила цей документ 19 грудня 2011 р. [8].

Зобов'язання держав щодо вживання заходів у галузі навчання прав людини пов'язані також із діяльністю регіональних міжнародних організацій. Членство України в Раді Європи передбачає, що держава буде слідувати численним рекомендаціям із навчання прав людини. Так, у Резолюції (78) 41 (1978р.) Комітету міністрів Ради Європи рекомендовано урядам включити викладання прав людини в навчальну програму для школярів, студентів, викладачів, державних службовців. Рекомендація $\mathrm{R}$ (85) 7 Комітету міністрів держав-членів Ради Європи «Про викладання й вивчення прав людини в школах» від 14 травня 1985 р. закликала уряди до заохочування викладання та вивчення прав людини в школах, залучаючи до цього осіб та організації, які займаються шкільною освітою. Комітет міністрів Ради Європи в 1999 р. прийняв Декларацію та Програму виховання громадян у дусі демократії, усвідомлення ними своїх прав та обов'язків. Цього ж року заснована посада Комісара з прав людини, який має сприяти здійсненню інформаційно-просвітницької діяльності в галузі прав людини.

Рада Європи запровадила програму «Освіта, спрямована на виховання демократичної громадянськості» (1997р.). Головною ідеєю цієї програми стала теза, що громадянськість - це всеосяжне юридичне, політичне, соціальне та морально-етичне поняття. Формування демократичної громадянськості в суспільстві передбачає користування правами людини й почуття власного захисту з боку демократичного суспіль- ства всіма його членами, усвідомлення того, що кожен має бути залучений до питань суспільного життя, а також діяти як активний і відповідальний громадянин, який поважає права інших. Із цим, безумовно, пов'язані різні елементи культури прав людини. 2005 рік Рада Європи проголосила Європейським роком громадянськості. Завдяки цьому в усіх державах Європи відбулася активізація діяльності державних органів та інститутів громадянського суспільства у сфері освіти. Українська держава також не залишилася осторонь і залучилася до цієї просвітницької акції.

Важливо, що Рада Європи розробила й упровадила освітню програму HELP (навчання у сфері прав людини для представників юридичних професій). Вона спрямована на популяризацію європейських цінностей, прав людини та демократіі. В Україні ця програма також презентована й знайшла відгук серед громадськості.

Організацію навчальних заходів 3 прав людини здійснює Українська Гельсінська спілка з прав людини. Вона бере участь у розробленні комплексної національної політики сфери освіти в галузі прав людини. Це відбувається в рамках Всеукраїнської освітньої програми «Розуміємо права людини» (РПЛ). Така освітня програма є єдиною неформальною системою освіти, яка має власну матеріальну базу діяльності - Освітній дім прав людини, що знаходиться в Чернігові. Ця освітня програма заснована у 2007 р., спрямована на інкорпорування цінностей і принципів прав людини в систему формальної освіти. Передбачався також розвиток неформальної освіти в галузі прав людини, що, безумовно, сприяло культивуванню культури поваги прав людини. Такими діями зміцнювалася повага до верховенства права в Україні, формувалося міжкультурне порозуміння й принципи мирного вирішення всіх конфліктних ситуацій. Натепер РПЛ пишається понад 3500 випускниками по всій Україні [2]. 
Важливим моментом є той факт, що Українська Гельсінська спілка 3 прав людини у співробітництві з Секретаріатом Уповноваженого Верховної Ради України з прав людини, а також за участі інших громадських організацій упровадила ініціативу «Національний індекс прав людини». Здійснювався моніторинг виконання Національної стратегії з прав людини, простежувалося впровадження місцевого індексу прав людини, створеного для врахування пріоритету прав людини в процесі реформи децентралізації.

В Україні для зростання та підвищення культури поваги до прав людини, а також відповідно до європейських стандартів Українська Гельсінська спілка з прав людини протягом 20142017 років виконувала програму за підтримки Агентства США з міжнародного розвитку (USAID).

Очевидним $€$ той факт, що освіта в галузі прав людини - це життєво необхідна умова запобігання порушенням прав людини. Вона також $€$ найважливішим внеском у формування справедливого суспільства, де будуть поважати права кожного його члена, з високим рівнем культури прав людини. Досягнення результатів у цій галузі відбудеться тільки з урахуванням ефективного міжнародного співробітництва та в разі діалогу всіх зацікавлених сторін, а ще забезпечення права людини знати свої права.

Поряд з освітнім напрямом у формуванні культури прав людини важливу роль відіграє також науково-дослідний складник. Дослідження різних аспектів прав людини в кандидатських і докторських дисертаціях 3 юридичних, політичних, історичних, філософських наук, створення нових напрямів науки прав людини, відкриття наукових лабораторій, ініціативних науково-дослідних груп 3 підготовки колективних робіт, наукових праць із прав людини, студентських гуртків, спеціалізованих кафедр. Дуже важливим $є$ розвиток i вдосконалення досвіду юридичних клінік, що сприяє формуванню в сту- дентів знань, умінь і навиків, здобуття цінного досвіду дотримання й захисту прав і свобод людини та громадянина.

Вагомими представниками вітчизняної юридичної науки, наукових центрів, що на постійній основі досліджують проблематику прав людини, $\varepsilon$ Національна академія правових наук України (зокрема Львівська лабораторія прав людини і громадянина НДI державного будівництва та місцевого самоврядування з незмінним славетним керівником П.М. Рабіновичем (доктор юридичних наук, професор, академік НАПрН України) - автором численних наукових праць з прав людини), Національний університет «Юридична академія України імені Ярослава Мудрого», Інститут держави і права ім. B.M. Корецького НАН України.

Варто звернути увагу також на діяльність Лабораторії дослідження теоретичних проблем прав людини, створеної на основі юридичного факультету Львівського національного університету ім. Івана Франка. Керівником лабораторії став кандидат юридичних наук, доцент С.П. Добрянський. У колективній монографії співробітників лабораторії пропонується привести Конституцію України до більшої відповідності міжнародним «праволюдинним» стандартам, доповнення конституційного тексту новими правами, визначеними в новітніх актах Організації Об'єднаних Націй і Ради Європи. Наголошується також необхідність відображення на конституційному рівні положення про пріоритетну юридичну силу міжнародних договорів у системі джерел права України, відступу від обмеження у відповідних статтях Конституції тільки констатацією назв прав і свобод людини та громадянина, резонності в усіх випадках пояснювати головні елементи змісту того чи іншого права. Запропоновано також під час закріплення всіх прав людини вказувати відповідні позитивні обов'язки держави щодо забезпечення цих прав. Підстави обмеження прав людини та громадянина, на думку нау- 
ковців, варто скоректувати в такий спосіб, щоб вони не були ширшими, ніж зазначені обмеження в ратифікованих державою міжнародних договорах. В окремих статтях Конституції варто уточнити назву носіїв прав: «людина», «особа», «громадянин», «об'єднання» [7].

У дисертаційному дослідженні С.П. Добрянського зазначено, що «суттєвою ознакою формування пан'європейської культури прав людини можна вважати поступове подолання колізій у сфері судового захисту тих прав людини, котрі можна захистити в рамках двох міжнародно-правових систем, - систем, які є рівноправними та несубординованими (в той час як раніше цілком реальним було прийняття різних за змістом рішень у схожих за своїми базовими, «фабульними» ознаками справах 3 прав людини, одна 3 яких (справ) становила предмет розгляду Євросуду з прав людини, а інша - Суд справедливості Європейського союзу)» $[4$, с. 161].

Отже, права людини у XXI столітті стали загальновизнаною цінністю в усьому цивілізованому світі. Без них неможливо оцінити всю систему складних політичних, соціальних, економічних, правових, міжнародних відносин. Права людини $є$ масштабним складником культури людства. Високий рівень культури прав людини - це одна з гарантій їх реалізації.

Міжнародно-правові стандарти з освіти й виховання в галузі прав людини $€$ пріоритетним складником формування культури прав людини. Реалізація державами зобов'язань, що випливають із відповідних універсальних i регіональних міжнародно-правових актів, є необхідною умовою побудови сучасного соціуму на засадах таких цінностей, як мир, повага до прав людини та людської гідності, толерантність, відмова від насильства й міжкультурне розуміння. Інкорпорування цінностей i принципів прав людини в систему освіти й науки України, стимулювання наукових дослі- джень у галузі прав людини особливо із залученням молоді - це ефективні кроки підвищення рівня культури прав людини, становлення демократичної громадянськості в суспільстві та поваги до верховенства права.

Сучасний стан формування культури людських прав в Украӥні та світі характеризується неоднозначністю й суперечливістю. З одного боку, людські права майже одностайно визнаються иінністю загальнолюдської культури, існує розгалужена система міжнародних стандартів та інституцій щзодо їх регламентаціï й захисту. 3 іншого боку, повага до людських прав, ї дотримання, гарантування нівелюються й знецінюються в умовах сучасних міжнародних збройних конфліктів, катастроф техногенного характеру, зменшення матеріальних i природних ресурсів тощо.

Рівень культури людських прав як окремих індивідів, так й українського суспільства загалом не є високим. Це зумовлено й історичним минулим (адже індивідуалізм, у контексті якого розвивалися уявлення про людські права на Заході, не притаманний українському суспільству), i реаліями сьогодення. Тимчасова окупація територій $i$ неоголошена війна в Україні є серйозним викликом людським правам, фактично спростуванням поваги до людського життя й людської гідності. У такій ситуації важливо, щуоби як громадяни, так і представники державних структур мали знання у сфері людських прав і навички щодо їх реалізаціï ma захистy.

Метою статті $е$ дослідження освітнього й науково-дослідного напрямів формування культури людських прав як основи демократії та циивілізованої держави, аналіз міжнародно-правових стандартів $і$ нациіонального досвіду.

Вагому роль у формуванні культури прав людини в сучасній Укра- 
їнській державі відіграє міжнародне співробітництво. Інформування громадськості про права людини здійснюеться в рамках діяльності міжнародних $i$ регіональних організацій.

Освіта в галузі прав людини - ие необхідна умова запобігання порушенням прав людини, а також важливий внесок у проиес організаиіі справедливого суспільства. Таке суспільство характеризується повагою до прав кожного його илена, високим рівнем культури прав людини. Досягнення вагомих здобутків можливе лише на основі ефективної міжнародної співпраці, діалогу всіх сторін, досконалого забезпечення права людини знати свої права.

Поряд із освітнім напрямом у формуванні культури прав людини важливу роль відіграе також науково-дослідний складник. Дослідження різних аспектів прав людини в кандидатських $і$ докторських дисертаціях з юридичних, політичних, історичних, філософських наук, створення нових напрямів науки прав людини, відкриття наукових лабораторій, ініціативних науково-дослідних груп з підготовки колективних робіт, наукових праць із прав людини, студентських гуртків, спеціалізованих кафедр. Дуже важливим є розвиток $i$ вдосконалення досвіду юридичних клінік, що сприяе формуванню в студентів знань, умінь і навиків, здобуття иінного досвіду реалізації, охорони, захисту прав людини.

Головними векторами формування культури прав людини в украӥнському суспільстві сьогодні є реалізація зобов'язань, які випливають з універсальних $i$ регіональних міннародних нормативно-правових актів, спрямованих на виховання всіх верств населення й забезпечення належних умов для проведення юридичних досліджень у галузі прав i свобод людини.

Ключові слова: права людини, культура прав людини, освіта в галузі прав людини.
Donchenko O., Bunchuk O. Culture of human rights: international legal standards and national experience

The current state of the formation of culture of human rights in Ukraine and in the world is characterized by ambiguity and contradiction. On the one hand, human rights are almost unanimously recognized as the value of universal culture, and there are an extensive system of international standards and institutions for their regulation and protection. On the other hand, the respect for human rights, their observance, guarantees are levelled and devalued in the conditions of modern international armed conflicts, disasters of anthropogenic nature, reduction of material and natural resources, etc.

The level of culture of human rights, both of separate individuals and Ukrainian society as a whole, is not high. It is due to the historical past (because individualism, in the context of which the concept of human rights was developed in the West, was not inherent in Ukrainian society) and the realities of the present. Temporary occupation of the territories and the unannounced war in Ukraine are a serious challenge to human rights, actually, it is refutation of respect for human life and human dignity. In such a situation, it is important for both citizens and government officials to have knowledge of human rights and skills in their implementation and protection.

The purpose of the article is to study the educational and research areas of the formation of culture of human rights as the basis of democracy and a civilized state, an analysis of international legal standards and national experience.

Cooperation within the framework of international organizations, implementation of obligations arising from universal and regional international legal acts, that are aimed at training and education in the spirit of human rights of all strata of the population and professional groups, is of special significance for the formation of culture 
of human rights in our time in Ukraine. For a long time, various international and regional organizations have been campaigning for public information on human rights.

Education in the field of human rights is a vital condition for prevention of human rights violations and the most important contribution to the formation of a just society in which everyone's rights will be appreciated and respected, a high level of human rights culture will be formed. To achieve results in this area is possible only on the basis of effective international cooperation and dialogue of all interested parties, as well as ensuring the human right to know their rights.

An important place in the formation of the culture of human rights, along with the educational direction is the research component, namely the development of human rights ideas in candidate's and doctoral dissertations on historical, political, legal and philosophical sciences, the development of new areas of human rights science, the creation of scientific laboratories, initiative research groups and collectives for the preparation of collective monographs, encyclopedias on human rights, scientific student circles, specialized human rights departments, legal clinics.

The priority directions in the formation of human rights culture in the modern Ukrainian society are the implementation of the obligations arising from universal and regional international legal acts aimed at training and education, in the spirit of human rights, of all layers of population and professional groups, as well as creation of conditions and encouragement of conducting scientific research in the field of human rights and freedoms and applied research in legal science.

Key words: human rights, culture of human rights, education in the field of human rights.

\section{Література}

1. Горбова Н.А. Правова культура та культура прав людини: співвідношення понять та шляхи імплементациї. Порівняльно-аналітичне право. 2017. № 1. C. 16-18.

2. Дайджест Української Гельсінської спілки з прав людини (УГСПЛ). 2017. № 11 (33). URL: https://helsinki.org.ua/ articles / najtsikavisha-informatsiya-proprava-lyudyny-za-zhovten-2017-roku/.

3. Декларащія принципів толерантноcmi вid 16.11.1995. URL: http://zakon2. rada.gov.ua/laws/show/995_503.

4. Добрянський С.П. Актуальні проблеми загальної теорії прав людини : дис. ... канд. юрид. наук : 12.00.01. Одеса, 2003. $180 \mathrm{C}$

5. КОМПАС : посібник з освіти в галузі прав людини за участі молоді. URL: https: / / ww.coe.int/uk/web/compass / home.

6. План дій на Десятилітmя з освіти в галузі прав людини Організації Об'єднанux Hauiü. 1995-2004 рокu. URL: http:// www.un.org / ru/documents / ods.asp? m=A/ $51 / 506 /$ Add.1.

7. Права людини й оновлення Конституціi України : пр. лабораторії дослідження теоретичних проблем прав людини юрид. фак. Львівського нац. ун-ту імені Івана Франка. Львів : Малий видавн. иентр юрид. фак. Львівського нац. ун-ту імені Івана Франка, 2011. Bun. 5. URL: http://law.lnu.edu.ua/ uploads / media /Vipusk_5.pdf.

8. Декларація Організації Об’єднаних Націй щодо освіти та навчання у галузі прав людини: Резолюція Генеральної Асамблеї ООН 66/137 від 19 грудня 2011 р. URL: http: / / www.un.org / ru/ga/third /66 / third_res.shtml.

9. Рекомендація про виховання в дусі міжнародного взаєморозуміння, співробітництва й миру та виховання в дусі поваги прав людини і основних свобод від 19.11.1974. URL: http: / / zakon3.rada.gov.ua/ laws / show/995_863.

10. Робинсон М. Образование в области прав человека - наше общее дело. Российский вестник «Международной амнистии». 2001. № 21. C. 9-11.

11. Складові частини загальної стратегії ЮНЕСКО з прав людини від 20.09.2002. URL: http: / / unesdoc.unesco.org / images / 0012 / 001274 / 127405r.pdf. 